\section{Alternate Bearing Intensity of Pecan Cultivars}

\author{
Patrick J. Conner ${ }^{1}$ and Ray E. Worley \\ Department of Horticulture, University of Georgia, Coastal Plain Experiment \\ Station, 4604 Research Way, Tifton, GA 31793
}

Additional index words. biennial bearing, fungicides, tree age, nut quality, yield, breeding, selection

\begin{abstract}
The Coastal Plain Experiment Station has been evaluating pecan [Carya illinoinensis (Wangenh.) K. Koch] cultivars for over 75 years. Using annual yield data from this program, the alternate bearing intensities $(I)$ of 66 pecan cultivars and numbered U.S. Dept. of Agriculture (USDA) selections were determined. Values ranged from 0.19 to 0.93 in young trees, and from 0.27 to 0.91 in mature trees under high-input production practices. The adoption of fungicides, insecticides, and irrigation during the last 30 years has reduced the average $I$ value from 0.70 to 0.55 . $I$ was negatively correlated with both nut yield and nut weight. All but one cultivar recommended for commercial production in Georgia have $I$ values lower than the average of 0.57 for all cultivars in this test. Values calculated early in a tree's productive life cycle were highly correlated with those of mature trees.
\end{abstract}

The tendency of fruit trees to bear fruit in 2-year cycles, consisting of a large crop followed by little or no crop, is termed alternate or biennial bearing. Alternate bearing occurs in almost all tree-fruit crops, but is especially severe in pecan (Monselise and Goldschmidt, 1982). This severity is linked to three traits inherent to pecan: 1) the time of fruit maturity; 2) the nature of fruit growth; and 3) the chemical composition of the kernel (Sparks, 1974). In contrast with many fruit crops, pecan fruit matures late in the growing season, leaving little time prior to leaf fall for carbohydrate storage to support the next season's developing flowers and fruit. In addition, most of the dry matter of the nut accumulates at the end of the season. Finally, kernels contain $\approx 70 \%$ lipids, which require considerable energy to produce. These traits, when combined with a heavy fruit-set, can leave trees depleted of carbohydrate reserves, especially in the roots, at the end of the season and contribute to poor fruit-set the following year(Malstrom, 1974; Smith and Waugh, 1938; Wood, 1989).

Fruit quality can be poor during years of excessive fruiting ("on" year) and a low or medium yield is obtained the following year ("off" year). Improved horticultural practices have reduced the severity of alternate bearing in pecan. The most important techniques for reducing alternation center around manipulating the environment to prolong leaf retention, thereby increasing carbohydrate reserves available for the next season (Wood, 1999; Worley, 1979a, 1979b, 1973). Chief among

Received for publication 6 Dec. 1999. Accepted for publication 29Feb. 2000. The cost of publishing this paper was defrayed in part by the payment of page charges. Under postal regulations, this paper therefore must be hereby marked advertisement solely to indicate this fact.

${ }^{1}$ To whom requests for reprints should be addressed. E-mail address: pconner@tifton.cpes.peachnet.edu these methods are the control of leaf pests, increasing exposure to sunlight through pruning and tree removal, and ensuring adequate water and nutrient content of the soil. During wet years, pecan scab [Cladosporium caryigenum (Ell et Lang.) Gottwald] can result in total crop losses in susceptible varieties (Sanderlin, 1994). Losses of crops to scab might increase $I$ values for susceptible cultivars above those obtained when scab is controlled with fungicides. Fungicide sprays also protect leaves from scab and other leaf diseases, including downy spot (Mycosphaerella caryigena Demaree and Cole) and fungal leaf scorch (unknown etiology). These diseases can result in premature leaf drop, which reduces nut set the following year (Dodge, 1966; Worley and Harmon, 1969). At present, chemical fruit thinning in pecan is not practical, although mechanical thinning can reduce the severity of alteration in certain cultivars (Smith and Gallott, 1990).

Despite advances in horticultural methods, alternate bearing remains a key production problem. The tendency for alternation is an important factor in selecting cultivars for orchard establishment and identification of those most useful in breeding. Selection of cultivars with reduced tendency to alternate is the first and most important step in managing alternate bearing. A useful method for the quantification of alternate bearing is through the measurement of its intensity, I (Pearce and Doberšek-Urbanc, 1967). All that is required for this measurement is several successive years of yield data on individual trees. $I$ varies from a minimum of 0 (identical yields every year) to a maximum of 1 (complete alternation with no yield every other year). The Coastal Plain Experiment Station in Tifton, Ga., has been evaluating pecan cultivars for over 75 years. Annual yield has been recorded on individual trees, enabling the determination of the long-term alternate bearing habit of many of the most common cultivars and breeding program selections. Over 35 years of yield data are available for many of these trees, allowing the comparison of the alternate bearing habit of trees in both young and mature stages. Here we report the first quantitative measure of the alternate bearing intensity of 66 pecan cultivars and selections and its association with nut quality and yield.

\section{Materials and Methods}

Orchard establishment The first cultivars were planted in 1921, with additions made periodically through 1982 . The first trees planted at the station were spaced at $12.2 \times 12.2 \mathrm{~m}$. The center tree of the earliest planting was removed in 1944 to relieve crowding. The planting was extended in 1955 into an adjacent orchard spaced at $12.2 \times 15.3 \mathrm{~m}$. Usually, four trees of each cultivar were planted, but occasionally additional trees of 'Woodard', 'Farley', 'Elliot', 'Stuart', 'Van Deman', and 'Desirable' were added as replacement trees so that not all trees of these cultivars were planted at the same time. In 1979, a new orchard spaced at $12.2 \times 12.2 \mathrm{~m}$ was established nearby with cultivars and selections from the USDA breeding program. Four trees of each cultivar were included and randomized within years.

Orchardmaintenance. Records are not available on fertilizer rates or other cultural practices utilized during the early years of the test, but we assume that the best production practices of the time were used. The severity of alternate bearing is highly dependent upon tree culture and management strategies. This is especially important in this study, which has been ongoing for several decades. During this time, trees went from essentially no culture other than basic ground cover maintenance and fertilization to a high input culture that includes insect control, disease control, and irrigation. These major changes in the level of inputs have doubtless impacted the bearing habit of the trees. Trees were sprayed with insecticides beginning in 1962 and fungicides beginning in 1970. Insecticides were applied only when pest populations were high, and fungicides were applied according to Univ. of Georgia recommendations. Since 1962, trees received $112 \mathrm{~kg} \cdot \mathrm{ha}^{-1} \mathrm{~N}$ annually, plus other nutrients and lime when leaf analysis or soil analysis indicated need. Drip irrigation began in the orchards in 1975. Irrigation is applied through six emitters per tree each supplying $3.8 \mathrm{~L} \cdot \mathrm{h}^{-1}$ when the matric potential reaches -0.01 bar. Microsprinkler irrigation has been used in the newer planting with water applied from one microsprinkler per tree. Selective limb pruning has been practiced annually in the two station orchards since 197475 to hold trees within the allotted space.

Data analysis Yields were obtained from 1921 to 1999 . From 1921 to 1996 , total nut yield per tree was obtained by harvesting each tree independently by hand or harvester. Beginning in 1996, yields were estimated by shaking trees and then measuring the weight of nuts in a wedge-shaped section consisting of $1 / 100$ of the area under the tree. This measurement was replicated four times for each tree and the weights summed and multiplied by 25 to obtain the total tree yield. Beginning in 1969, a 50-nut 
Table 1. Alternate bearing intensity $(I)$ of pecan cultivars and selections at Tifton, Ga.

\begin{tabular}{|c|c|c|c|c|c|c|}
\hline \multirow[b]{3}{*}{ Cultivar } & \multirow{3}{*}{$\begin{array}{l}\text { No. } \\
\text { trees }\end{array}$} & \multirow{3}{*}{$\begin{array}{l}\text { Year planted } \\
\text { (no. trees) }\end{array}$} & \multicolumn{4}{|c|}{ Alternate bearing intensity $(I)$ and SD } \\
\hline & & & \multicolumn{2}{|c|}{ Young trees $^{2}$} & \multicolumn{2}{|c|}{ Mature trees ${ }^{y}$} \\
\hline & & & Fungicide $^{\mathrm{x}}$ & No fungicide $^{w}$ & Fungicide & No fungicide \\
\hline Alley & 2 & 1921 & --- & $0.65(0.06)$ & -- & $0.74(0.09)$ \\
\hline Big Z & 3 & 1922 & --- & $0.62(0.05)$ & $0.36(0.04)$ & $0.70(0.04)$ \\
\hline Bradley & 3 & 1921(1); 1922(1) & --- & $0.72(0.14)$ & $0.57(0.09)$ & $0.62(0.09)$ \\
\hline Brooks & 3 & 1940 & --- & $0.81(0.08)$ & $0.56(0.09)$ & $0.85(0.06)$ \\
\hline Burkett & 2 & $1929(1) ; 1930(1)$ & --- & $0.52(0.12)$ & $0.29(0.04)$ & $0.59(0.03)$ \\
\hline Cape Fear & 7 & $1955(4) ; 1979(3)$ & $0.41(0.06)$ & --- & $0.53(0.03)$ & --- \\
\hline Cherokee & 2 & 1977 & $0.93(0.06)$ & --- & $0.91(0.10)$ & --- \\
\hline Cheyenne & 3 & 1979 & $0.65(0.11)$ & --- & --- & --- \\
\hline Creek & 3 & 1981 & $0.70(0.12)$ & --- & --- & --- \\
\hline Curtis & 3 & 1921 & --- & $0.71(0.06)$ & $0.59(0.03)$ & $0.78(0.08)$ \\
\hline Davis & 2 & 1956 & --- & $0.38(0.18)$ & $0.40(0.02)$ & --- \\
\hline Delmas & 3 & 1921 & --- & $0.81(0.12)$ & $0.67(0.09)$ & $0.80(0.05)$ \\
\hline French & 2 & 1974 & $0.51(0.03)$ & --- & $0.53(0.07)$ & --- \\
\hline Frotscher & 3 & 1921 & --- & $0.78(0.07)$ & --- & $0.89(0.05)$ \\
\hline Gloria Grande & 6 & 1955(2); 1979(4) & $0.19(0.06)$ & $0.23(0.00)$ & $0.27(0.00)$ & --- \\
\hline Grabohl & 4 & 1979 & $0.70(0.10)$ & --- & --- & --- \\
\hline Harris & 3 & 1956 & --- & $0.69(0.05)$ & $0.75(0.03)$ & --- \\
\hline Hastings & 3 & $1956(1) ; 1960(2)$ & $0.38(0.14)$ & --- & $0.36(0.04)$ & --- \\
\hline Ivy & 3 & 1964 & $0.32(0.04)$ & --- & $0.42(0.06)$ & --- \\
\hline Kiowa & 3 & 1979(2); $1982(1)$ & $0.59(0.09)$ & --- & --- & --- \\
\hline Linberger & 4 & 1979 & $0.48(0.10)$ & --- & --- & --- \\
\hline Mahan & 3 & 1928(2); $1929(1)$ & --- & $0.75(0.04)$ & $0.74(0.08)$ & $0.80(0.04)$ \\
\hline Mahan-Stuart & 2 & 1964 & $0.41(0.17)$ & --- & $0.40(0.01)$ & --- \\
\hline Maramec & 4 & 1981 & $0.54(0.01)$ & --- & --- & --- \\
\hline Melrose & 4 & 1981 & $0.79(0.16)$ & --- & --- & --- \\
\hline Mobile & 3 & 1921 & --- & $0.72(0.03)$ & $0.68(0.03)$ & $0.77(0.08)$ \\
\hline Pensacola Cluster & 3 & 1964 & $0.34(0.05)$ & --- & $0.38(0.04)$ & --- \\
\hline President & 3 & 1921(1); 1922(2) & --- & $0.66(0.10)$ & $0.59(0.21)$ & $0.66(0.07)$ \\
\hline Robinson & 4 & 1979 & $0.84(0.04)$ & --- & --- & --- \\
\hline San Saba & 3 & 1929(2); 1930(1) & --- & $0.88(0.01)$ & $0.85(0.02)$ & $0.85(0.02)$ \\
\hline Schley & 3 & 1921 & --- & $0.72(0.07)$ & $0.60(0.02)$ & $0.76(0.01)$ \\
\hline Shawnee & 4 & 1979(3); 1980(1) & $0.90(0.03)$ & --- & --- & --- \\
\hline Shoshoni & 3 & 1979 & $0.63(0.06)$ & --- & --- & --- \\
\hline Stuart & 5 & $1921(3) ; 1964(1) ; 1970(1)$ & $0.35(0.09)$ & $0.57(0.12)$ & $0.47(0.07)$ & $0.58(0.07)$ \\
\hline Success & 3 & 1921 & --- & $0.72(0.13)$ & --- & $0.57(0.05)$ \\
\hline Summers & 3 & 1921 & --- & $0.84(0.03)$ & $0.43(0.11)$ & $0.83(0.03)$ \\
\hline Sumner & 7 & 1940(2); 1981(1); 1982(4) & $0.46(0.16)$ & $0.72(0.13)$ & $0.55(0.03)$ & $0.77(0.03)$ \\
\hline Tejas & 4 & 1979(3); 1980(1) & $0.77(0.08)$ & --- & --- & --- \\
\hline Tesche & 3 & 1921(1); 1922(2) & --- & $0.43(0.12)$ & $0.44(0.15)$ & $0.56(0.13)$ \\
\hline Van Deman & 6 & 1921 & --- & $0.47(0.18)$ & $0.44(0.07)$ & $0.66(0.10)$ \\
\hline Western Schley & 3 & 1929 & --- & $0.65(0.03)$ & $0.56(0.10)$ & $0.79(0.02)$ \\
\hline Wichita & 3 & 1970 & $0.51(0.12)$ & --- & $0.67(0.06)$ & --- \\
\hline Williamson & 3 & 1929 & --- & $0.61(0.10)$ & $0.81(0.15)$ & $0.70(0.06)$ \\
\hline Woodard & 13 & $1956(2) ; 1964(10) ; 1966(1)$ & $0.43(0.15)$ & --- & $0.35(0.04)$ & --- \\
\hline USDA 40-9-266 & 4 & 1979 & $0.64(0.09)$ & --- & --- & --- \\
\hline USDA 53-11-139 & 5 & 1981(4); 1982(1) & $0.35(0.05)$ & --- & --- & --- \\
\hline USDA 53-9-1 & 4 & 1981(3); 1982(1) & $0.85(0.11)$ & --- & --- & --- \\
\hline USDA 57-7-22 & 3 & 1981 & $0.64(0.14)$ & --- & --- & --- \\
\hline USDA $62-5-8$ & 3 & 1979 & $0.30(0.02)$ & --- & --- & --- \\
\hline USDA 64-11-17 & 3 & 1981 & $0.63(0.08)$ & --- & --- & --- \\
\hline
\end{tabular}

${ }^{2}$ Calculated from yield of years 9-20.

${ }^{\mathrm{y}}$ Calculated from yield of years $9-30+$.

${ }^{\mathrm{x}}$ Calculated using yield data primarily obtained after 1970 from trees that received regular fungicide sprays.

${ }^{\text {w}}$ Calculated using yield data primarily obtained prior to 1970 from trees not receiving fungicide sprays. 
sample was collected from each tree for quality analysis. Nuts were shelled and percentage of edible kernel was calculated by weight. Kernel yield was calculated by multiplying total nut yield $\times$ percentage of kernel/100. Specific gravity is the average nut volume/average nut weight. Percentage of fill is the percentage of the volume inside the nut that is filled with kernel. Percentage of fill was calculated by the equation: $\%$ fill $=100 \times$ kernel volume $/($ nut volume - shell volume), and all volumes were determined by water displacement. The fluctuation in yield was expressed in terms of alternate bearing intensity $(I)$, calculated as $I=$ $1 /(\mathrm{n}-1) \times\left\{\left|\left(\mathrm{a}_{2}-\mathrm{a}_{1}\right)\right| /\left(\mathrm{a}_{2}+\mathrm{a}_{1}\right)+\left|\left(\mathrm{a}_{3}-\mathrm{a}_{2}\right)\right| /\left(\mathrm{a}_{3}\right.\right.$ $\left.\left.+a_{2}\right) \ldots+\left|\left(a_{(n)}-a_{(n-1)}\right)\right| /\left(a_{(n)}+a_{(n-1)}\right)\right\}$, where $\mathrm{n}=$ number of years, and $\mathrm{a}_{1}, \mathrm{a}_{2}, \ldots, \mathrm{a}_{(\mathrm{n}-1)}, \mathrm{a}_{\mathrm{n}}=$ yields of corresponding years (Pearce and Doberšek-Urbanc, 1967). To calculate $I$ for trees early in their productive life cycle, yield data from growing seasons 9-20 (9-18 and 917 for trees planted in 1981 and 1982, respectively) were used. To determine $I$ for mature trees, all yields after year 9 were used as long as at least 20 years of data were available. Values of $I$ were calculated for each tree individually and then data for all trees were combined and averaged to estimate $I$ for the cultivar. Associations between $I$ and yield and quality measurements were determined by Pearson product moment correlation coefficients using mean values for each cultivar. Only data from the newer planting (trees planted in 1979, 1981, and 1982) were used in determining correlations among nut yield and kernel yield and $I$, because these trees were all of similar age, spacing, and culture.

\section{Results and Discussion}

In order to examine the effect of fungicides on the alternate bearing habit of the cultivars, the yield data were divided into those obtained prior to 1970 , when fungicide applications began (low-input), and those obtained after 1970 (high-input). In most cases, $I$ values calculated from low-input years were higher than those from high-input years (Table 1). The decrease in $I$ values ranged from $50 \%$ in 'Big Z' and 'Summers' to none in several cultivars. On average, mature tree $I$ values decreased from 0.70 under low inputs to 0.55 $(P<0.001)$ under high inputs. $I$ values based on data before 1970 are more applicable to minimum input strategies, whereas values obtained after 1970 reflect performance under modern high-input production practices and should be used when comparing cultivars for use in commercial orchards. Note, however, that these data are confounded with tree age, which also affects $I$.

Much variation was present among cultivars for $I$ in both young and mature trees (Table 1). In young trees, I ranged from 0.19 for 'Gloria Grande' to 0.93 for 'Cherokee'; in mature trees, it ranged from 0.27 to 0.91 in the same cultivars. $I$ was negatively correlated with nut yield (Table 2), indicating that, on average, high production in the "on" years does not make up for low production in "off" years. The importance I plays in the success of

Table 2. Pearson correlation coefficients between nut quality and yield traits and alternate bearing intensity $(I)$.

\begin{tabular}{|c|c|c|c|c|c|c|c|}
\hline Parameter & No. obs. & $I$ & Kernel (\%) & Fill (\%) & $\begin{array}{c}\text { Mean } \\
\text { nut yield }\end{array}$ & $\begin{array}{c}\text { Mean } \\
\text { kernel yield }\end{array}$ & Nut size \\
\hline Kernel (\%) & 62 & NS & & & & & \\
\hline Fill $(\%)$ & 62 & NS & $0.349^{* *}$ & & & & \\
\hline Mean nut yield & 27 & $-0.419^{*}$ & NS & NS & & & \\
\hline Mean kernel yield & 27 & NS & NS & NS & $0.907^{* *}$ & & \\
\hline Nut size & 62 & $-0.294^{*}$ & NS & NS & NS & NS & \\
\hline Specific gravity & 62 & NS & NS & $0.867^{* *}$ & NS & NS & NS \\
\hline
\end{tabular}

* Significant at $P \leq 0.05$.

** Significant at $P \leq 0.01$.

${ }^{\mathrm{N}}$ Nonsignificant.

a cultivar is highlighted by the fact that all cultivars except one that have been recommended for commercial use in Georgia(Worley and Mullinix, 1994) ['Caddo' (0.32), 'Cape Fear' (0.41), Desirable (0.40), 'Farley' (0.39), 'Forkert' (0.53), 'Gloria Grande' (0.27), 'Stuart' (0.47), 'Sumner' (0.55), and 'Woodard' $(0.35)]$ have lower $I$ values than the average of 0.57 for all cultivars in this test. 'Elliot' $(0.68)$ is a severe alternate bearer but is recommended primarily because it produces high quality nuts in the "on" year and is highly resistant to scab.

Cultivars with a strong tendency to alternate often produce large crops of poor quality kernels in the "on" year followed by small or no yields in the "off" year (Sparks, 1974). I was not correlated with nut quality, as measured by percentage of kernel, percentage of fill, or specific gravity (Table 2). However, these cultivars are not a random sample of pecan germplasm, but rather a collection of cultivars selected for above average yield and nut quality. Thus, strongly alternating cultivars with consistently poor quality during the "on" year would probably not have been selected for use in these trial plantings.

The production of new cultivars with reduced yield fluctuations is a major goal of the USDA pecan breeding program (Thompson and Grauke, 1999) and of the newly established pecan breeding program at the Univ. of Georgia (Conner, 1999). Alternation in yield often is not exhibited in young trees that are undergoing the transition from the nonfruiting stage to the mature stage because not enough shoots are fruiting to deplete carbohydrate reserves (Sparks, 1974). However, to be efficient in developing new cultivars, breeding programs must evaluate new selections as quickly as possible. To determine the number of years of data needed to predict $I$ for mature trees, $I$ was calculated for all trees for which $\geq 35$ years of yield data were available, beginning in year 9, for the first 5-year period, the first 10-year period, the first 15-year period, and for all years together. Mature tree $I$ values were highly correlated $(P \leq 0.0001)$ with those obtained from the first 5-year period (0.872), the first 10 -year period (0.898), and the first 15 -year period (0.943). Thus, alternate bearing can be evaluated within the framework of current replicated yield trials that typically evaluate trees for 15 to 20 years. The inclusion of these data in yield trial reports should be useful in helping to predict the success of new pecan cultivars.

\section{Literature Cited}

Conner, P.J. 1999. The Georgia pecan breeding program. Proc. Southeastern Pecan Growers Assn. 92:77-80.

Dodge, F.N. 1966. Control of foliage diseases of pecans. Proc. Southeastern Pecan Growers Assn. 59:72-74.

Malstrom, H.L. 1974. The relationship of stored reserves to yield in mature pecan trees. Proc. $8^{\text {th }}$ Annu. West. Pecan Conf. p. 65-69.

Monselise, S.P. and E.E. Goldschmidt. 1982. Alternate bearing in fruit trees. Hort. Rev. 4:128173

Pearce, S.C. and S. Doberšek-Urbanc. 1967. The measurement of irregularity in growth and cropping. J. Hort. Sci. 42:295-305.

Sanderlin, R.S. 1994. Effect of nut scab on pecan yield and quality components, p. 45-58. In: M.W. Smith, W. Reid, and B.W. Wood (eds.). Sustaining pecan productivity into the $21^{\text {st }}$ century; Proc. Second Natl. Pecan Wkshp., U.S. Dept. Agr.-Agr. Res. Serv.

Smith, M.W. and J.C. Gallott. 1990. Mechanical thinning of pecan fruit. HortScience 25:414416

Smith, C.L., and J.G. Waugh. 1938. Seasonal variations in the carbohydrate and nitrogen content of roots of bearing pecan trees. J. Agr. Res. 57:449-460.

Sparks, D. 1974. The alternate fruit bearing problem in pecans. Annu. Rpt. North. Nut Growers Assn. 47:145-158.

Thompson, T.E. and L.J. Grauke. 1999. General ideas about genetic improvement in pecan, $\mathrm{p}$. 74-78. In: B. McGraw, E.H. Dean, and B.W. Wood (eds.) Proc. Third Natl. Pecan Wkshp. U.S. Dept. Agr.-Agr. Res. Serv.

Wood, B.W. 1999. Alternate bearing of pecan, p. 180-187. In: B. McGraw, E.H. Dean, and B.W. Wood (eds.) Proc. Third Natl. Pecan Wkshp. U.S. Dept. Agriculture-Agr. Res. Serv.

Wood, B.W. 1989. Pecan production responds to root carbohydrates and rootstock. J. Amer. Soc. Hort. Sci. 114:223-228.

Worley, R.E. 1979a. Pecan yield, quality, nutlet set and spring growth as a response to fall defoliation. J. Amer. Soc. Hort. Sci. 104:192-194.

Worley, R.E. 1979b. Fall defoliation date and seasonal carbohydrate concentration of pecan wood tissue. J. Amer. Soc. Hort. Sci. 104:195199

Worley, R.E. 1973. Pecan nutlet set and carbohydrate level of various tissues in the spring as affected by fungicide sprays. J. Amer. Soc. Hort. Sci. 98:68-71.

Worley, R.E. and S.A. Harmon. 1969. Effect of fungicides on nutlet set of pecans. HortScience 4:127-128

Worley, R.E. and B.G. Mullinix. 1994. Pecan cultivar performance at the Coastal Plain Experiment Station, 1921-1994. Georgia Agr. Expt. Sta. Bul. 426. 